\title{
Forest Watershed and Riparian Disturbance Project (FORWARD)
}

\author{
by Preston McEachern ${ }^{1}$
}

\begin{abstract}
The Forest Watershed \& Riparian Disturbance Project (FORWARD) was initiated in 2001 to study hydrologic and water quality impacts and recovery following watershed disturbance in the Boreal Forest. Now in its third phase, FORWARD continues to assess long-term recovery following forest harvest and fire and has extended research to recovery of reclaimed oil sands mine sites. Numerical models developed in the first phases are now being applied to the determination of watershed load and contaminant fate from the mine sites. The development of reclaimed and engineered soils, the success of various vegetation complexes, and the risk of toxicity and impacts to bio-indicators are being compared to the findings from the decade of continuous data collected during FORWARD 1 \& 2 that sets our expectations for watershed recovery. The previous results indicate that runoff coefficients were strongly correlated with disturbance intensity with recovery for many key indicators (e.g. nutrient loading) occurring over three to six years. In the case of harvesting, no detectable changes were observed below $50 \%$ harvest intensity, and wetlands played a crucial role in mitigating hydrologic and water quality impacts obscuring the role of riparian buffers in this same function. The data collected by the FORWARD Project has been used to improve forest management practices and improve SWAT runoff modeling in the boreal forest, which can be used in forest management planning. Specific results from the first phase of FORWARD are outlined in this summary.
\end{abstract}

\section{RÉSUMÉ}

Cet article passe en revue les origines et les résultats de quelque 50 années de travaux de recherche effectués dans le bassin versant expérimental de Marmot Creek, appelé maintenant Bassin de recherche Marmot Creek. Marmot Creek a été créé afin de mieux comprendre comment utiliser les interventions forestières pour gérer les hydrogrammes de débit et a subi plusieurs interventions dans les années 1970 et 1980. Même s'il est connu que les petites éclaircies forestières augmentent systématiquement l'accumulation de la neige, leur effet sur la vitesse de fonte dépendait de la superficie de léclaircie, de sa pente et de sa forme. Les traitements par éclaircie, qu'ils prennent la forme de grands blocs ou de petites troués, nont donc eu qu’un effet limité sur la chronologie et la variabilité des hydrogrammes du débit et un effet localisé sur son volume. Ces modifications du climat se sont principalement manifestées par un réchauffement qui réduit considérablement l'accumulation de neige sur les terrains peu élevés. Ces changements du climat ne se traduisent pas par des changements dans les hydrogrammes et il n'y a pas de tendance manifeste dans les volumes ou la chronologie de lécoulement au cours des 50 dernières années. Dans son ensemble, le site démontre une résilience remarquable aux changements de climat et d'utilisation du territoire en raison de sa vaste gamme d'altitudes, de pentes, d'environnements neigeux et de réserves souterraines. Le site est devenu un observatoire des processus hydrologiques servant à concevoir et évaluer des modèles multiéchelles destinés à des sites plus étendus. Il a joué un rôle déterminant dans ce cas précis, et les résultats scientifiques obtenus à Marmot Creek ont servi à élaborer des modèles climatiques mondiaux et des modèles hydrologiques qui sont maintenant en usage partout dans le monde.

\section{Introduction}

The Forest Watershed \& Riparian Disturbance Project (FORWARD) was started in 2001 (Table 1) as a partnership between researchers, industry professionals (mining, energy, and forestry), and government institutions (provincial and federal) to study the hydrologic and water quality impacts and recovery following watershed disturbance (harvest, fire, mountain pine beetle; Fig. 1) with the view to improving landscape management (Smith et al. 2003; Table 2). The program grew over successive iterations to include ecological indicators such as amphibians, aquatic toxicity (acute, chronic and behavioral) and to mine reclamation of whole watersheds. FORWARD, now in its third funding cycle, has four research components:

- Component 1. Watershed load and contaminant fate modelling is developing models that allow industry and regulators to manipulate the landform designs of proposed mine closure plans to ensure the desired hydrologic and biogeochemical outcomes and ultimately successful reclamation of watersheds occurs;

- Component 2. Benchmarks for reclaimed and engineered soils is characterizing physical, biogeochemical and microbial features of oil sands sites and their changes through time and compares these states and changes to those in reference, burned and forest/ reforested soils;

- Component 3. Acceptable vegetation complexes: impacts and recovery after disturbance is comparing vegetation recovery trajectories after oil sands activity to trajectories after reforestation treatments for wildfire and harvest activities, as a means to predict mid- to late stage vegetation recovery trajectories for reclaimed mine sites; and,

- Component 4. Risk of toxicity and impacts to bio-indica-

${ }^{1}$ Department of Civil \& Environmental Engineering, University of Alberta, Edmonton, AB, Canada; preston@ualberta.ca 
tors from anthropogenic load is characterizing acute and chronic toxicity to amphibians, macroinvertebrates and fish of organic and inorganic contaminants associated with oil sands extraction. Amphibians are a focus because of their known sensitivity to broadly distributed low-level contaminants, particularly trace organic compounds.

\section{Results}

Burn

\section{Nutrients}

- Total dissolved phosphorus (TDP) and particulate phosphorus (PP) exports remained elevated in the burned watersheds, compared to pre-fire conditions, for at least four years after the fire (Burke et al. 2005)

\section{Streamflow}

- Runoff increased in the burned watersheds compared to the reference watersheds for at least six years (Pelster et al. 2008)

- During rain-dominated years, peak flows were higher in burned watersheds compared to reference watersheds (Burke et al. 2005)

- During a snow-dominated year, peak flows were reduced in burned watersheds relative to reference watersheds, likely due to snowpack sublimation and early melt (Burke et al. 2005).

\section{Harvest}

\section{Nutrients}

- Stormflow (hydrograph peak and recession) showed higher TDP and PP concentrations in the harvested streams compared to reference streams during the growing season (Prepas et al. 2008b)

- In autumn, TDP concentrations were higher in harvested streams compared to reference streams. PP concentrations were similar in harvested streams compared to reference streams during the rising limb, but lower in the harvested streams at storm peaks and during the falling limb (Prepas et al. 2008b)

- During baseflow, differences in TDP and PP concentration in harvested and reference streams were undetectable (Prepas et al. 2008b)

- TDP and PP exports (normalized to precipitation input) were higher in harvested streams than reference streams by $153 \%$ and $130 \%$, respectively, in the first year following the harvest (Prepas et al. 2008b)

- $30 \mathrm{~m}$ riparian buffers did not reduce TDP or PP exports.

- Nitrate and ammonium exports were higher in harvested watersheds than in reference watersheds by $130 \%$ and $170 \%$, respectively (Pelster et al. 2008)

- In general, it was suggested "that harvest intensity (less than $50 \%$ of a watershed) was more important than riparian buffers" in reducing impact of forest harvest (Prepas et al. 2008b: p S75) and increased runoff as represented by runoff coefficients from harvested watersheds responded similarly to burned watersheds initially but recovered more quickly (five years) to pre-disturbance values.

\section{Temperature}

- There was no significant change in stream temperature post-harvest with $30 \mathrm{~m}$ buffers (Prepas et al. 2008b).

- Stream temperature increased post-harvest with no riparian buffers (Prepas et al. 2008b).

\section{Vegetation}

- Vascular plant abundance increased after harvest at buffered and cut-to-shore sites following a decline in year 1.

- Non-vascular plant abundance decreased linearly over time in both harvest treatments.

- Vascular \& non-vascular response was more pronounced in cut-to-shore.

- Species diversity did not differ between harvested and ref-
Table 1. Summary of the FORWARD Project watershed and climatic characteristics

\begin{tabular}{ll}
\hline & Watershed location data \\
Location (descriptive) & Swan Hills is located $20 \mathrm{~km}$ northwest of \\
& Whitecourt, Alberta \\
Location (geographic) & Between $54^{\circ} 15^{\prime}$ and $54^{\circ} 40^{\prime} \mathrm{N}$ latitude \\
& $116^{\circ} 20^{\prime}$ and $115^{\circ} 50^{\prime} \mathrm{W}$ longitude \\
Biogeoclimatic zone & Western Canadian Boreal Plain \\
Watershed areas & Large watersheds: $129-247 \mathrm{~km}^{2}$ \\
& Small watersheds: $2.6-15.6 \mathrm{~km}^{2}$ \\
Elevation range (a.s.l.) & $845-1030 \mathrm{~m}$ \\
Precipitation (mean annual) & 580 mm \\
Temperature & Daily Average: Jan: $-12.1^{\circ} \mathrm{C}$ \\
& July: $15.7^{\circ} \mathrm{C}$ \\
& Mean annual: $2.6^{\circ} \mathrm{C}$ \\
\hline
\end{tabular}

${ }^{*}$ Prepas et al. 2008b and Smith et al. 2003

** Data obtained from 1971-2000 Canadian Climate Normals (EC) for Whitecourt, AB

Table 2. Study design and measured variables for the FORWARD Project

\section{Research design}

Study type

Before/After, Control/Impact

Treatments

Harvest: three watersheds with no buffer around stream: Sakwatamau B, Millions, and Pierre two watersheds with $30 \mathrm{~m}$ buffer around stream: Kashka, and Toby

Burn: four watersheds: Sakwatamau A, Goose, Burnt Pine, and Fireweed

Controls

seven Reference watersheds: Two Creek, Chickadee, Willow, Thistle, Cassidy, 1A, and Mosquito

Study duration $2001-$ Present

Variables measured Stream discharge; water level and temperature; water quality: nutrients, colour, dominant ions, suspended sediment, $\mathrm{pH}$, alkalinity, and turbidity (water collected using "grab" samples and automated samplers); vegetation and soil plots; soil moisture and hydraulic conductivity; groundwater (wells and piezometers); meteorological stations: temperature, relative humidity, precipitation, solar radiation, wind speed, and wind direction. 


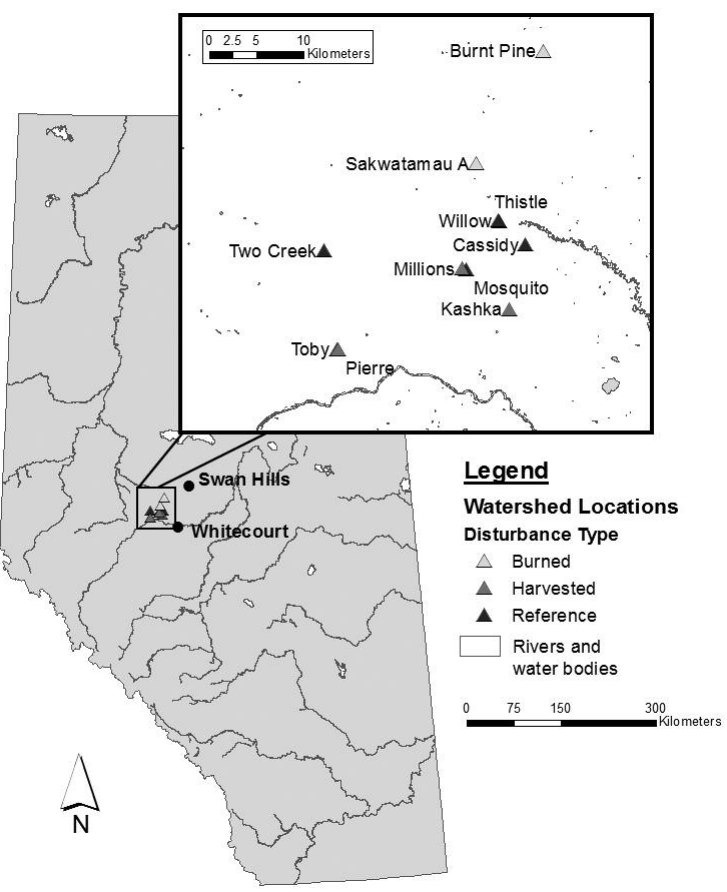

Fig. 1. Location of the hydrometric monitoring stations in the FORWARD research program.

erence sites, nor did it change with distance from stream channel.

- Riparian plant assemblages were more resilient to winter than summer harvest.

\section{Management/Operational Results}

- The development of predictive tools (e.g., streamflow models, runoff coefficients) were used by Millar Western to improve forest management planning by predicting how the proposed forest management would affect streamflow and water quality (Prepas et al. 2008a).
- The proportion of wetland cover in a watershed was a main factor in runoff generation for reference watersheds (higher cover resulted in higher runoff coefficients) and on the magnitude of harvest impact (higher wetland cover resulted in smaller increases in runoff coefficient).

- The role of wetlands in mitigating impacts to runoff following harvesting obscured any mitigating influence of riparian buffers.

- Impacts from harvesting on runoff coefficient were strongly correlated with harvest intensity with no detectable impact at harvest intensity below $50 \%$.

- The runoff model SWAT, modified for the boreal forest (SWATbf), could accurately predict runoff, particularly for monthly averages where NSE of 0.8 was achieved. The model was subsequently used in integrated forest management planning to meet regulatory requirements in Alberta.

\section{References}

Burke, J.M., E.E. Prepas and S. Pinder. 2005. Runoff and phosphorus export patterns in large forested watersheds on the western Canadian Boreal Plain before and for 4 years after wildfire. J. Environ. Eng. Sci. 4: 319-325.

Pelster, D., J.M. Burke and E.E. Prepas. 2008. Runoff and inorganic nitrogen export from Boreal Plain watersheds six years after wildfire and one year after harvest. J. Environ. Eng. Sci. 7 (Suppl. 1): 51-61. Prepas, E.E., G. Putz, D.W. Smith, J.M. Burke and J.D. MacDonald. 2008a. The FORWARD Project: objectives, framework and initial integration into a Detailed Forest Management Plan in Alberta. Forest. Chron. 84: 330-337.

Prepas, E.E., J.M. Burke, G. Putz and D.W. Smith. 2008b. Dissolved and particulate phosphorus concentration and export patterns in headwater streams draining Boreal Plain watersheds one year after experimental forest harvest and post-harvest silvicultural activities. J. Environ. Eng. Sci. 7 (Suppl. 1): 63-77.

Smith, D.W., E.E. Prepas, G. Putz, J.M. Burke, W.L. Meyer and I. Whitson. 2003. The Forest Watershed and Riparian Disturbance study: a multi-discipline initiative to evaluate and manage watershed disturbance on the Boreal Plain of Canada. J. Environ. Eng. Sci. 2 (Suppl. 1): 1-13. 